\title{
A filosofia do direito penal nas "Confissões" de Santo Agostinho (*)
}

\author{
Alexandre Augusto de Castro Corrêa \\ Docente Livre de Direito Romano na Universidade
de São Paulo
}

Poucos autores terão como Santo Agostinho nas "Confissões" penetrado tão fundo a consciência do homem, procurando descobrir e efetivamente descobrindo a origem do mal moral, do pecado e da vontade perversa do criminoso; a breve descrição do furto das peras revela através um episódio da agitada vida do Santo a essência do delito como produzida pelo "prazer do malefício", fôrça ínsita no coração humano, responsável por tôdas as violações da lei penal.

Nos tempos modernos só talvez Dostoyewsky se tenha elevado ao mesmo plano, ao mostrar em "Crime e Castigo" a lei psicológica e moral obrigando Raskolnikow a voltar ao lugar do crime e através o tormento da consciência confessar afinal, o homicídio praticado contra a velha usurária.

É conhecida a passagem das "Confissões"; no livro segundo, contando a "Adolescência", narra Santo Agostinho o furto $(2, \mathrm{IV}, 9)$; procura depois $(2, \mathrm{v}, 10-11)$ as causas ordinárias dos delitos e dos crimes; mostra (2, vi, 12-14) como no pecado cometido na infância, nada mais procurou senão o mal pelo mal; ao lembrar sem temor a falta

(*) Limitamo-nos a traduzir em português, sem comentários além dos iniciais o trecho das "Confissões". Servimo-nos da edição bilingue francesa publicada pela "Société d'Édition Les Belles Lettres", Paris, 1925, sob a direção de Pièrre de Labriolle. 
cometida (2, vII, 15) sabe ter sido perdoado por Deus; termina (2, vIII, 16-18) analisando sob o aspecto psicolóvico o prazer da cumplicidade.

Encontramos nêstes capítulos, sintetizada no estilo nervoso e belo de Santo Agostinho, tôda a filosofia do Direito Penal.

A lei divina pune sem dúvida o furto assim como o punem os homens, através a lei inscrita em seus corações. Esta lei nem mesmo a iniquidade dêles a apaga ("quam ne ipsa quidem delet iniquitas"); com efeito, quê ladrão suporta com indiferença ("aequo animo") o furto praticado contra si próprio? Nenhum rico perdôa o indigente, movido pela aflição. Èle, porém, (Agostinho) furtara impelido tão só pela penúria e fastídio do sentimento de justiça, pelo excesso de iniquidade ("penuria et fastidio justitiae et sagina iniquitatis").

Como praticou a ação maligna? Havia uma pereira na vizinhança da vinha pertencente à familia e as peras não eram atraentes ("inlecebrosae") nem pela beleza, nem pelo sabor.

Para cometerem o furto ficaram Agostinho e seus companheiros ("nequissimi adulescentuli") na praça pública até altas horas da noite, como aliás costumavam, segundo péssimo hábito ("de pestilentiae more").

Furtaram grande quantidade de peras não para comer mas para atirar aos porcos; e si provaram algumas foi antes pelo prazer de praticar uma ação proibida ("dum tamen fieret a nobis quid eo liberet, quo non liceret")

Narrados o fato e seu motivo, exclama o Santo: "Eis meu coração ó Deus, eis meu coração do qual te apiedaste no fundo do abismo! ("in imo abyssi".) (Êsse coração procurava o mal gratuitamente e a causa única de sua maldade era a própria maldade.

Hedionda ("foeda") era a maldade e êle a amara; amara a própria morte, a própria queda ("defectum") e não o objeto destas! Alma torpe, separada para seu extermínio do firme apoio divino e nada mais apetecendo, 
através a ignomínia ("dedecus") senão própria ignomínia.

Encontramos aqui a antítese perfeita da "boa vontade" Kantiana, justamente considerada inestimável pelo filósofo de Koenigsberg. Além de revelar no homem a existência da inclinação instintiva para o mal, mostra Santo Agostinho como, na ordem psicológica, a proibição dum ato suscita no destinatário da proibição, o desejo de violá-la.

Quais as causas ordinárias dos crimes? As coisas belas, o ouro, a prata, exercem atração ("species") sôbre o llomem; o prazer do contacto físico desperta a maior simpatia e esta é o elemento preponderante daquele. Cada seniido encontra nas coisas corpóreas a modalidade a êle correspondente.

A honra mundana e o poder de mandar e dominar ("imperitandi atque superandi potentia") tem igualmente seu preço. Nasce daí a avidez da vingança ("vindictae aviditas"). E no entanto, no esfôrço pela obtenção de tais bens não deve o homem se afastar de Deus nem de sua lei.

Nossa própria vida, neste mundo, tem encanto, devido à relativa beleza que lhe é própria e à harmonia com tôdas estas belezas terrestres ("..propter quendam modum decoris sui et convenientiam cum his omnibus infimis pulchris").

Também a amizade entre os homens é doce por causa dos caros laços unindo muitas almas.

Em razẩo destas coisas e outras semelhantes, surge em nós a ocasião de pecar ("peccatum admittitur"), enquanto a inclinação imoderada para elas, apesar de inferiores nos faz abandonar bens superiores e mais elevados, afastando-nos de Deus, de sua verdade e de sua lei ("...tu, domine Deus noster et veritas tua et lex tua"). Com efeito, as coisas mundanas exercem também sua sedução, muito diversa entretanto da exercida por Deus, autor delas tôdas, pois nele se deleita o justo. Êle é a delícia dos corações retos ("...in ipso delectatur justus, et ipse est deliciae rectorum corde"). 
Procurando, pois, a causa dum crime, só nos contentaremos descobrindo o desejo de aquisição ou o medo da perda de alguns daqueles bens por nós chamados ínfimos.

Belos são êles, possuindo seu prestígio, embora comparados aos bens superiores e beatíficos, sejam abjetos e baixos.

Alguém cometeu homicídio? Foi por cobiçar a mulher ou os bens da vítima; ou então para, roubando, adquirir meio de vida.

Pode ainda haver temido sofrer dano semelhante por parte de alguém; finalmente ofendido, sentiu ardente desejo de vingança. Poderia ter morto sem causa só pelo prazer de matar? ("ipso homicidio delectatus"?) Quem o admitiria? Dum homem, verdadeiro monstro de demência e crueldade ("vaecordi et nimis crudeli homine") se disse: "Mesmo sem motivo, ("gratuito") amava a maldade e a crueldade".

O historiador ${ }^{1}$ indica entretanto uma razão: o criminoso assim procedia para a inércia não lhe entorpecer as mãos e o espírito. $\mathrm{E}$ porque se exercitava? Para, mediante a constante prática do crime, tomar Roma e conquistar honras, poder, riquezas, libertando-se do temor das leis e das dificuldades nas quais o enredavam a escassez de seu patrimônio e a consciência dos delitos praticados.

Portanto, nem o próprio Catilina amou o crime pelo crime e sim pelos fins, através dêste colimados.

E êle, Agostinho, quê amou no furto, no delito noturno dos dezesseis anos? Não era belo o furto; seria mesmo alguma coisa, permitindo falar-se dêle? Belas eram as peras furtadas, criaturas de Deus, Sêr de suprema beleza, Criador de tôdas as coisas, Deus bom, Sumo Bem e Verdadeiro Bem do homem; belas eram as peras, mas a miserável alma de Agostinho não as cobiçara a elas mesmas. Êle tinha em abundância frutos melhores. Colhera as peras

(1) Trata-se de Sallustio, um dos clássicos mais apreciados pelas escolas africanas, desde o $\mathrm{II}^{\circ}$ até ${ }^{\circ} \mathrm{V} .^{\circ}$ século de nossa era. 
tão só para furtar. Pois, uma vez colhidas, deitara-as fora, degustando ("epulatus"), apenas a própria iniquidade, saboreada com delícia. E se algum daqueles frutos lhe entrou pela boca, o sabor dêles ("condimentum"), foi o do pecado.

Pergunta, então Santo Agostinho: qual a sedução sôbre êle exercida pelo furto, si êste nenhuma beleza possui? Não fala na beleza da justiça e da prudência, nem naquela residindo na inteligência humana, na memória, nos sentidos, na vida animal. Nem na dos astros, com suas órbitas grandiosas ou na da terra e do mar, cheios de sêres vivos, renovando-se graças à permanente sucessão, nem, finalmente, nesta beleza defeituosa e aparente, pela qual nos enganam os vícios.

O orgulho assume ares d'elevação d'alma, quando sô Deus paira acima de todos os sêres. A ambição procura apenas as honras e a glória, quando só a Deus acima de tudo, pertencem honra e glória eternas. 0 rigor ("saevitia") dos poderosos quer ser temido: quem, entretanto, excepto Deus, deve ser temido? Quando, onde, para onde, por quem se pode arrancar ou subtrair qualquer coisa ao poder d'Ele? Os libertinos querem se fazer amar pelas carícias, mas, nada existe mais carinhoso do que a divina caridade, nem amor há mais salutar que o da Verdade divina, bela e luminosa acima de tôdas. A curiosidade afeta a aparência de zêlo científico, enquanto Deus tudo sabe integralmente. A própria ignorância e a estultice se cobre com o nome de simplicidade e inocência, enquanto nada existe mais simples que Deus. E haverá inocência maior que a divina? As obras dos maus são dêles inimigas.

A preguiça ("ignavia") finge só procurar o repouso; entretanto quê repouso seguro se encontrará fora do Senhor? o luxo quer ser chamado saciedade e abundância: Deus entretanto, é plenitude e abundância inesgotável de incorruptível delícia.

A prodigalidade ("effusio") usurpa as formas da liberalidade. Deus porém é o dispensador ("largitor") opulentíssimo de todos os bens. 
A avareza quer possuir muito e Deus tudo possui. A inveja ("invidentia") luta pela pré-eminência: haverá entretanto, algo superior a Deus? A ira procura vingança: e quem se vinga mais justamente que Deus? 0 temor receia as coisas insólitas e repentinas, contrárias às coisas amadas, enquanto provê à segurança destas; para Deus, porém, haverá algo de insólito? Algo de repentino? Ou quem separa Deus do objeto de seu amor? Ou, onde, senão n'Êle, encontrar firme segurança? A tristeza se consome ("contabescit") por haver perdido os bens nos quais se deleitava sua cupidez: ela desejava lhe fôsse, como a Deus, impossivel perder qualquer coisa.

Assim, fornica ("fornicatur") a alma, desviando-se de Deus e procurando fora d'Êle aquêles bens, os quais em sua pureza sem mistura ("pura et liquida") só se encontram em Deus. Imitam-no ao revés ("perverse") todos quantos d'Êle se apartam e contra Êle se voltam. Mesmo assim, porém, mostram ser Deus o Criador de tôda a natureza sendo por isso mesmo impossível ao homem divorciar-se completamente d'êle. Quê amara, pois, Agostinho, no furto? De que modo culposo e insensato imitara o Senhor? Procurara pela fraude, não o podendo fazer pela fôrça, violar a lei divina, nisto encontrando prazer. Simulara, verdadeiro escravo, então, uma liberdade falsa, praticando impunemente, por tenebrosa paródia da onipotência divina, o que lhe era proibido.

Ei-lo, o escravo, fugindo ao dono e procurando a sombra. Ó corrupção ("putredo") ó aberração de vida, ó abismo de morte! Tudo quanto era vedado pudera ùnicamente por isso, seduzir a Agostinho?

Agradece em seguida, ao Senhor por se lembrar de tais coisas sem medo. Deseja amar a Deus, dar-lhe graças e exaltar seu nome, por lhe terem sido perdoadas, a êle Agostinho, tantas ações más e criminosas. A graça e a misericórdia divinas dissolveram como gelo, seus pecados. Atribui ainda o Santo a Deus todo o mal que não praticou, pois quantos crimes poderia ter cometido, amando, como amara, o crime pelo crime? 
Deus tudo lhe perdoou, tanto o mal voluntàriamente praticado quanto o não praticado, graças à intervenção d’êle. Quê homem, com efeito, considerando a própria fraqueza, ousa atribuir à si mesmo a castidade e a inocência, a ponto de amar a Deus como si não precisasse da misericórdia com a qual Êle perdôa a todos quantos para Êle se voltam?

Quem, chamado por Deus e dócil ao apêlo evitou as faltas confessadas por Agostinho, não censure a êste por se haver curado graças à intervenção do médico ao qua] o inocente deve a própria saúde ou o fato de não ter adoecido tão gravemente. Ame pelo contrário ainda mais ao Senhor, pois Êle o preservou do esgotamento mortal dos pecados, dos quais, vê Agostinho se libertar por influência do mesmo Senhor.

Qual o benefício auferido pelos atos maus, dos quais não se pode lembrar sem enrubecer? Qual sobretudo o resultado daquele furto, praticado exclusivamente por amor ao furto? Quê era, aliás, o furto em si mesmo? Nada; e êsse nada tornava ainda mais lamentável o caso de Agostinho.

Ele não teria, entretanto, (recordava-se bem de sua disposição intima), certamente não teria cometido o furto sòzinho. Amara, também, por conseguinte a companhia daqueles com os quais furtara.

Neste sentido, era inexato dizer ter amado o furto em si mesmo; em outro sentido porém era exato, pois a própria cumplicidade não passava de puro nada.

Quê houvera, pois, na verdade? Quem poderia comunicá-lo a Agostinho, senão Aquêle que ilumina o coração dissipando-lhe as trevas? Qual a causa levando-o a tais indagações, discussões e considerações? Si gostasse, então, dos frutos subtraídos desejando regalar-se com êles, poderia, mesmo sòzinho, sendo isso bastante, cometer a ação vil, afim de obter a satisfação procurada, sem precisar inflamar o prurido de sua cupidez pelo contacto excitante de almas cúmplices ("nec confricatione consciorum animorum accenderem pruritum cupiditatis meae"). 
Como, porém, nenhum prazer encontrava Agostinho nos frutos, tal prazer advinha para êle da própria falta, cometida junto com outros. ("...ea erat in ipso fascinore, quam faciebat consortium simul peccantium").

Como penetrar semelhante estado d'espírito? Era sem dúvida torpe e ai dêle, Agostinho, por tal disposição dominado. Mas, afinal, em quê consistia?

Quem entende os delitos? ("delicta").

A alegria perversa estava num riso, fazendo, por assim dizer, cócegas no coração, à idéia de enganarem gente desprevenida e que por certo se indignaria.

E qual a razão fazendo Agostinho se deleitar tanto, por não agir só? Seria pelo homem desacompanhado não rir com facilidade?

A observação é em parte acertada; às vêzes, porém, mesmo solitário é o homem vencido pelo riso, como quando algo por demais cômico se lhe oferece aos sentidos ou à inteligência.

Êle, porém, só, de modo algum cometeria o delito.

Eis, perante Deus, a recordação viva de sua alma. Sòzinho não praticaria aquêle furto no qual lhe agradava não a coisa furtada, mas o furto mesmo: ("in quo me non libebat id quod furabar sed quia furabar").

E no entanto, si estivesse só, Agostinho nem furtaria nem desejaria furtar! $\delta$ amizade por demais inimiga! ("O nimis inimica amicitia"); incompreensivel ("investigabilis") sedução do espírito, avidez de malfazer nascida do brinquedo e do jôgo, apetite de causar dano a outrem, sem qualquer vestígio de desejo de lucro pessoal ou de vingança. Basta alguém dizer: "Vamos, façamo-lo!" e o pecador se envergonha de envergonhar-se “ vet pudet non esse impudentem").

Quem desvendará complicações tão tortuosas e inextricáveis? Elas representam uma vergonha na qual Agostinho não quer mais pensar e a qual não quer mais ver. Ele quer a Justiça e a Inocência divinas, belas e ornadas de puro brilho ("honestis luminibus") reservando gozos dos quais a alma não se sacia ("...insatiabili satietate"). 
Junto de Deus há paz prolongada e vida imperturbável; quem entra em Deus, entra no júbilo de seu Senhor, não temerá e viverá soberanamente bem no bem soberano ("...et habebit se optime in optimo").

Agostinho, na adolescência, desertou ("defluxit") para longe de Deus e errou, por demais afastado de Seu apoio, tornando-se assim, para si próprio uma "região de miséria" ("regio egestatis"). 